\title{
COMPARATIVE ANALYSIS ON CONTRACT SCHEME: SECURITY OR A PERIL
}

\author{
${ }^{*}$ Shonal Rath
}

B.A Economics (Hons), University of Delhi, New delhi- 110052

\section{ARTICLE INFO}

\section{Article History:}

Received $09^{\text {th }}$ March, 2021

Received in revised form

$21^{\text {st }}$ April, 2021

Accepted $04^{\text {th }}$ May, 2021

Published online $26^{\text {th }}$ June, 2021

\section{Key Words:}

Contract Farming, Smallholder farmers, Economic Indicators, State of Punjab, APMC Policy.

\section{*Corresponding author: Shonal Rath}

\begin{abstract}
Contract farming is usually seen as a useful mechanism to assist smallholders in overcoming market access constraints. However, in spite of economic benefits, high smallholder dropout rates from contract schemes are commonplace. The aim of this study is to postulate a mechanism that uses quantitative and qualitative data from the Indian States to show that smallholder farmers benefit from a resource-providing contract in terms of higher yields and incomes, but that most of them still regret their decision to participate within the contract scheme and would like to exit if they might. The analysis underlines that research that specialize in narrowly defined economic indicators alone cannot explain farmers' satisfaction with contracts and their dropout behaviour. The main problem within the contract scheme is insufficient information provided by the corporate. Farmers don't understand all the contract details, which results in substantial mistrust. Farmers believe that the corporate behaves opportunistically, as an example during the output weighing procedure, and these beliefs are significantly correlated with the farmers' wish to exit. Moreover comparing such an instance to recent spike in dissatisfaction amongst farmers in the Punjab state in India, followed by disregard for the Government of India's new found APMC Policy.
\end{abstract}

Copyright (C) 2021, Shonal Rath. This is an open access article distributed under the Creative Commons Attribution License, which permits unrestricted use, distribution, and reproduction in any medium, provided the original work is properly cited.

Citation: Shonal Rath. “Comparative analysis on contract scheme: security or a peril”, International Journal of Development Research, 11, (06), 4795347957.

\section{INTRODUCTION}

Contract farmer in which the terms of the sale are specified in advance (Grosh, 1994). It is an institutional response to the high risks and uncertainties in spot markets, which are often characterised by significant market failures. Contract farming can reduce these risks and uncertainties, and thus incentivise increased smallholder investments, leading to higher productivity and income (Eaton \& Shepherd, 2001; Key \&Runsten, 1999; Simmons, Winters, \& Patrick, 2005). Therefore, contract farming is often seen as a useful tool for poverty alleviation and rural development (Bellemare \& Lim, 2018; Otsuka, Nakano, \& Takahashi, 2016; Wang, Wang, \& Delgado, 2014). It is also seen as an efficient mechanism to link smallholder farmers to high-value supply chains (Nguyen, Dzator, \& Nadolny, 2015). The question whether contract farming is really beneficial for smallholder farmers has long been a subject of debate. One strand of literature raises concerns that contract farming leads to the exploitation of unpaid family labour (Clapp, 1994; Little \& Watts, 1994), and to overuse of the farmers' natural resources (Bijman, 2008). It is argued that contracts create unequal power relations, due to the monopsonistic nature of the company (Clapp, 1994; Little \& Watts, 1994; Oya, 2012). It is also argued that contracts lead to a loss of farmers' autonomy, unequal gender relations (Adams, Gerber,
\&Amacker, 2019; Bijman, 2008; Carney, 1998; Carney \& Watts, 1991; Schneider \& Kay, 2010; von Bülow\& Sorensen, 1993), and undesirable changes in social behaviour (Adams, Gerber, Amacker, \& Haller, 2019). A second strand of literature, mostly using quantitative research methods, provides evidence on positive effects of contract farming on production and household welfare. From an economics perspective, farmers with a contract typically benefit through higher yields (Champika et. al, 2014; Hernández, Reardon, \&Berdegué, 2007), higher revenues (Ashraf, Giné, \&Karlan, 2019, Qaim, 2021). A recent review of the existing empirical results showed that positive productivity effects were found in $92 \%$, and positive income effects in $75 \%$ of the cases (Wang et al., 2014). However, there may be a certain publication bias in the literature on contract farming, with positive results having a higher likelihood of being published than negative results (Ton, Vellema, Desiere, Weituschat, \&D'Haese, 2018). A recent study with representative data from six developing countries showed that contract farming had significantly positive income effects in only three of the six countries (Bellemare, 2012). In spite of positive income effects of contract farming in many situations, high smallholder dropout rates from contract schemes are often observed(Ngigi, 2004; Minot \& Sawyer, 2014; Narayanan, 2013, 2014; Ton et al., 2018). One reason for dropouts is that smallholders violate the contract conditions or are unable to consistently meet the quality requirements. However, there are also cases where farmers simply seem to be dissatisfied (Gatto et al., 
2017; Qaim, 2021). Thus, the debate around the development potential of contract farming is ongoing and requires additional research on potentials and constraints beyond narrowly defined economic indicators. In particular, farmers' satisfaction with contract farming is not yet sufficiently understood, but is important to reduce dropouts and facilitate lasting partnership between smallholder farmers and agribusiness companies.

\section{METHODOLOGY}

Our study aim is to research farmers' satisfaction with the contract farming scheme and possible reasons for dissatisfaction in spite of economic benefits. During the structured interviews, we asked all sample farmers two questions associated with their satisfaction. First, we asked whether or not they would sign the contract again if that they had the prospect to travel back in time. The aim of this question was to ascertain whether farmers regret having signed andaccepted the primary place. If this question was answered with 'no' (they wouldn't sign the contract again), we asked them for specific reasons. Second, we asked farmers if they might sign the contract again within the future after the present contract terminates if the contract terms remained unchanged. We then test whether the responses to those questions are correlated with per capita household income using Pearson's correlation coefficients. This correlation analysis helps to know whether farmers' satisfaction or dissatisfaction can be explained by income as an objective economic measure. a big correlation would indicate that farmers who are better or worse off are more likely to drop out, counting on the sign of the coefficient of correlation. In addition, we investigate information flows between the company and farmers and farmers' contract understanding, in order to test the common hypothesis that farmers rationally self-select into contract farming and are enabled to make informed decisions regarding their production investments. We examine the knowledge that farmers had about the contract prior to signing it and at the time of the survey. We also asked about farmers' ability to read and understand the contract and used two test questions about particular contract clauses. Further, we were interested to see whether farmers are aware of the size of their initial credit obtained through the contract.

Finally, we investigate the role of transparency and trust by looking at the example of timber fruit bunch weights, where farmers often feel deceived by the company. In the survey, we asked farmers whether they experienced a (perceived) weighing loss within the last 12 months prior to the survey, and for their estimated loss in tons of output. Answers to these questions are correlated with the satisfaction variables, in order to see whether issues of transparency and trust influence farmers' satisfaction and potential dropout behaviour. In particular, we provide statistics on the self-reported information farmers had about the contract when signing it and their level of contract understanding. The results challenge the common assumption that farmers rationally self-select into contract schemes and are enabled to make informed decisions about their production investments through proper information provided by the company (Bellemare, 2012). We also analyse problems that arise if farmers due to limited contract understanding - perceive the company's actions as opportunistic. While the specific results relate to the case of the timber contract in Brazil comparison with other examples from the literature suggests that similar problems of mistrust and lack of transparency also occur in many other contract schemes in various developing countries (Eaton \& Shepherd, 2020; Huacuja, 2016;

Torero, \&Qaim, 2014; Schipmann\&Qaim, 2011; Singh, 2012). Our results may encourage follow-up research to investigate the benefits and challenges of contracted smallholders beyond narrowly defined economic indicators.

The APMC, contract scheme and government's apprehension: During the National lockdown, the Agricultural Produce Market Committee (APMC) Act was withdrawn, the government accrued the possibility of removing it with ensuring mandatory purchase of of agricultural produce in local markets known as mandisas the chains of supply continued to remain unabridged even after withdrawal of the Act. The Act was especially withdrawn to do away with crowding at the Mandis. The direct sale and purchase of agricultural produce helped the agrarian sector to ensure sustainability of the lockdown. "Only sector that has not suffered during the Covid period despite the severest lockdown is agriculture. That is from where they (government) found that if they allowed direct buying and all that and proper supply lines are built then the system will function much better rather than this mandi system", explained Professor Gulati of University Of Delhi. Who gained from these MSPs: It was such that only $6 \%$ of the surveyed farmers had gained from this provision. A survey conducted had reviewed that the small felt exploited by private buyers under the new set of laws. This was conducted by Professor Gulati, who claimed that more the 90 per cent of the farmers sell their produce to private buyers. "Only six percent of the farmers have gained from the MSP even when MSP has existed since 1965",he said quoting the Shante Kumar panel report and the NSSO 70th round situation assessment survey.(Down to earth, 2021)

Region wise winners from this scheme: The narrative spread that dilapidated the fallacy that farmers from across the were protesting against the farm laws, Professor Gulati stated some figures and said that out of total 146 million farmers households in the country, Punjab accounts to 1.09 million farmer households. He said that the farmers from Punjab were the biggest beneficiaries of the MSP.

Reflective Introspection: India's agriculture sector makes a big contribution to its Gross Domestic Product and provides livelihood for several many people. Agriculture isn't only a way of trade and a source of livelihood, but is fundamentally related to our culture. Today though, farmers are distancing themselves from farming activities due to decreasing incomes and are watching alternative opportunities. These new developments will set into motion an exodus from villages to cities. Alternatively, within the hope of creating quick money from their farmlands, farmers are going to be keen on giving their land on a contract basis. Contract farming will convince be disastrous for the lives of many people in India who are related to the agriculture sector. How? allow us to have a glance.

Understanding from the basics: The Contract farming scheme works on a simple formula as it will give profitable organisations and corporations a way to entry into the agriculture sector. They proceed on to capturing markets such as Mandis as mentioned earlier. Recently, a provision made in Gujarat allows non-farmers to be given the status of a 'farmer', resulting in the possible misuse of this law. In India, agriculture and animal husbandry are complementary activities. Our economy, especially, the rural economy, is dependent upon both, agriculture and animal husbandry. Pastoralists do not have their own farms for grazing their flocks and herds. They usually take their animals to the grazing lands of the village, vacant lands or farms owned by farmers. Arrangements exist in many places where cattle graze in farms and fertilise them with their dung. However, if farmers were to entrust their lands to somebody on a contract basis, what will livestock feed on?. Next, the agricultural practice of cultivating more than one food grain in a single farm for retaining fertility of the land has been followed through generations. But a corporate that only intends to maximise profits and is engaged in contract farming, would least likely be interested in the preservation of land and soil. Sustainable development is not on the corporate agenda. Contract farming could entail foreign varieties being grown in India's fields. For millions, locally grown varieties of crops have provided nutrition and sustenance for centuries. If such varieties are gone, the population will suffer from malnutrition, as is the case in many places today. Farms cannot operate without labour. However, mechanised farming will receive enhanced importance in contract farming, resulting in a decrease in the numbers of farm labourers. Presently, the deployment of machinery in small-sized farms is uneconomic. But it would be the obvious option for a contractual farming agency possessing larger lands. Increasing rural unemployment would be the consequence. Contractual companies come only for profit. Farming becomes a business, not a way of life or a baseline that maintains the welfare and dignity of the family. Corporates neither look after the farmers' 
interests nor are interested in increasing the fertility of the timber. We have reliable scientific evidence that shows chemical fertiliser-based farming is harmful to health and causes tremendous damage to farmland. This development runs contrary to the attempts to maintain or switch to conventional or organic farming or cattle-based farming. In a democratic country, a farmer has the right to offer his land on contract basis. So, why are there concerns regarding farmland usage? The reason is that today, the government, by focusing on corporate expectations and interests, has ignored the rest of the country. Feeding India is a national and political obligation. However, the government has failed to recognise the importance of maintaining the quality of soil, traditional farming techniques and the social and economic fragility of communities operating on the margins of society. Contract farming is a novel idea but do short term gains merit the longer-term demerits?

\section{CASE STUDY}

Timber Procurement in Brazil in South American Continent and Hancock Timber Resource group: We collected quantitative data on the assembly and sales of all crops cultivated by the households and on all other income sources to calculate household income. Before the structured survey to gather quantitative data, we held focus group discussions in four villages with resource-providing contracts, which weren't sampled for the quantitative survey. Two sorts of focus group discussions were held in each of the four villages: First, we had a guided discussion with the village chief, the elder council, and therefore the lead farmers to debate the constraints farmers faced before and after the contract farming scheme started, how the corporate offered contracts within the village, and their selection criteria and cooperation with the informal village government. Second, we held focus group discussions with 10-20 farmers in each of the four villages. We didn't restrict participation for any farmer within the village and ensured attendance by both male and feminine contract farmers. In these group sessions with farmers we discussed feather palm production methods, marketing options, constraints, satisfaction, and challenges with the contract and therefore the contracting company.

\section{Table 1. Producer and Household Characteristics}

\begin{tabular}{lrr} 
& Mean & Std. Dev. \\
\hline Farmer ( $\mathrm{n}=169$ ) and household ( $\mathrm{n}=164$ ) characteristics & & \\
Gender (female $=1$ ) & 0.12 & 0.45 \\
Age (in years) & 15.78 & -15.9 \\
Education (in years) & 6.6 & -8.91 \\
Experience (in years) & 11.32 & -8.9 \\
Number of household members & 3.5 & -1.8 \\
Number of adult household members (18 years and older) & 2.85 & -1.3 \\
Number of youth household members (14-17 years) & 0.49 & -0.71 \\
Number of children in the household (<14 years) & 1.86 & -1.72 \\
Commercial timber production prior to contract farming (yesÂA $=\hat{A}$ ] & 0.45 & -0.5 \\
Independent timber production (yes = 1) & 0.21 & -0.41 \\
Land purchase since contract participation (in acres) & 6.92 & -2.34 \\
Number of other cash crops produced & 12.3 & -9.8 \\
Absolut area under timber cultivation (in acres) & 7.45 & -9.83 \\
Relative area under timber cultivation & 0.12 & -0.24 \\
Area under contract (in acres) & 8.93 & -6.93 \\
Years under contract & 3.56 & -0.81
\end{tabular}

Source: Ian Scoones: A research on Timber (2021)

Both sorts of focus group discussions included a group of lead questions, which were equal across villages, and a subsequent open discussion. Sessions were held within the local language and an area coordinator was present for English translations. Supported the knowledge derived from these focus group discussions, the questionnaire for the quantitative survey was extended to incorporate specific questions on farmers' satisfaction and complaints. Thus, building on information collected through the main target group discussions, we expanded the survey questionnaire to also capture data beyond purely economic indicators. Table 1 presents produce, the producer, and household characteristics of the households in our sample for the quantitative survey. The typical farm size is around 20 acres, albeit half-hour of the households even have but 10 acres of land. The typical area under contract is 8 acres. Most contracted farmers are male. On the average, farmers are 56 years old, have 7 years of formal education, and 16 years of experience in feather palm cultivation. Most households are under contract for 8-10 years. Before the contracts, only 45 you look after the households cultivated feather palm commercially (beyond just small quantities for home consumption). Additionally to grease palm, households grow other cash crops like cocoa and rubber and food crops like cassava and maize.

Farmers' Satisfaction: Table 2 presents mean values of farmers' answers to the satisfaction questions. Only 43 you look after the farmers don't regret having signed the contract and would sign it again under an equivalent conditions. Hence, quite half wouldn't sign the contract again. Several reasons are stated for the dissatisfaction. The foremost often mentioned reason relates to unfair contract terms, which indicates that farmers were unaware of truth contract features before signing the contract.

Table 2. Contract satisfaction $(\mathrm{N}=\mathbf{5 4 . 6})$

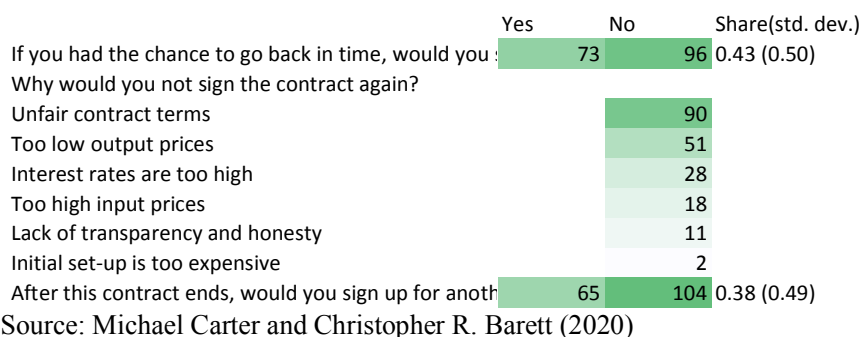

Especially, many farmers consider the output prices too low and therefore the interest rates and input prices too high. These answers indicate that farmers didn't make informed and rational choices once they signed the contract. Moreover, many farmers criticise the shortage of transparency and honesty of the corporate. Throughout the surveyed villages, farmers often reported that company representatives enter the farmland without informing the farmer. The output and input prices and related calculations and deductions are perceived as not transparent. In some cases, it had been reported that the corporate harvested a plot without prior knowledge of the farmer. Moreover, some farmers feel deceived because the initial information they received from the corporate was incomplete and therefore the initial promises made weren't met. Considering the widespread criticism, it's not surprising that only 65 you look after the farmers decide to sign a further round of an equivalent accept the longer term (Table 2). Whether farmers will really not check in the longer term and drop out of the scheme can't be observed at now. The scheme is in its first round of contracting, and therefore the current contracts will still continue for an additional 15-25 years.

Satisfaction Variables and Per Capita Household Income: Table 3 shows Pearson's correlation coefficients of the 2 satisfaction variables and per capita household income.

\section{Table 3. Per Capital Household Income \& Contract Scheme} Efficiency

Per capita household income
If you had the chance to go back in time, would you sign the contract again? 0.1458
After this contract ends, would you sign up for another one, if the contract terms remained unchanged? Source: Kevin H Zhang (2013)

We discover no statistically significant correlation between satisfaction and income. Moreover, both correlation coefficients are 
very small in magnitude, which supports the suspicion that farmers' satisfaction with the contract can't be explained by economic indicators alone.

Transparency: Lastly, we examine perceived opportunistic behaviour from the corporate by investigating incidences of weighing losses. The leads to Table 4 show that 45 you look after the farmers within the sample (78 farmers) experienced a minimum of one such perceived weight and weighing loss (Table 4). Out of the 78 farmers, 45 were ready to estimate the number of the loss in plenty of output. The typical stated loss within the 12 months before the survey is approximately 10 tons, which is like 87 you look after the typical annual yield per acre. Table 5 shows that this experience of at least one perceived weighing loss during the last 12 months is negatively correlated with the stated willingness to sign a new contract in the future. The correlation coefficient of -0.54 is statistically significant at the $5 \%$ level. Hence, lack of information and transparency, distrust, and dissatisfaction seem to be associated and possibly mutually reinforcing.

Table 4. Negative Correlation information, distrust and dissatisfaction

\begin{tabular}{|c|c|c|c|}
\hline Column1 & Number of farmers & Share & Std. Dev. \\
\hline $\begin{array}{c}\text { Experienced } \\
\text { at least one } \\
\text { weighing }\end{array}$ & & & \\
\hline loss & 76 & 0.91 & -0.12 \\
\hline $\begin{array}{l}\text { Ability to } \\
\text { estimate this }\end{array}$ & & & \\
\hline loss & 51 & 0.67 & -0.45 \\
\hline $\begin{array}{c}\text { Average } \\
\text { estimated } \\
\text { loss (in tons } \\
\text { of output) }\end{array}$ & 42 & 5.49 & -6.78 \\
\hline
\end{tabular}

Table 5. Experience of Contract Schemes

\begin{tabular}{|l|}
\hline \multicolumn{1}{|c|}{ Experience of at least one weighing loss } \\
\hline $\begin{array}{c}\text { If you had the chance to } \\
\text { go back in time, would } \\
\text { you sign the contract } \\
\text { again? }\end{array}$ \\
After this contract ends, \\
would you sign up for \\
another one if the \\
contract terms remained \\
unchanged?
\end{tabular}

SOURCE: Michael Carter and Christopher R. Barett (2020)

\section{RESULTS, OUTPUT AND DISCUSSION}

The results presented within the previous section on farmers' perceptions of contract farming within the Brazilian timber extraction sector have several important implications. They indicate that economic benefits alone cannot explain farmers' satisfaction with the contract scheme and their dropout behaviour. About half the farmers regret having signed, accepted the past and wouldn't sign the contract again within the future. Hence, the bulk of the farmers are dissatisfied with the accept spite of sizeable economic benefits. High dropout rates despite economic benefits are often observed within the existing literature (Minot et al., 2014; Ton et al. 2013). The willingness to sign another accept the longer term could also indicate that farmers would not require contractual support. This was reported, as an example, in reference to contract schemes in Thailand, India, and Indonesia (Euler et al., 2016; Narayanan, 2013). In those cases, farmers became wealthier through a few years of contract farming and will afterwards expand their plantations also without additional contractual support. In some cases, they also started investing into other businesses outside of agriculture (Narayanan, 2013). These examples from other countries suggest that not signing a contract again isn't necessarily an indicator of dissatisfaction. However, in our case the extent of dissatisfaction is sort of obvious through the mixture of answers to the 2 questions we asked about the past and therefore the future. Our data show that only 5 you look after the farmers who stated that they might not sign a replacement accept the longer term don't regret having signed the present accept the past. Furthermore, we showed that neither regretting having signed the contract nor being unwilling to sign a replacement contract is significantly correlated with household income. Hence, we conclude that the dissatisfaction isn't primarily driven by objectively measurable economic indicators.

Based on the criticism raised by farmers we analysed the knowledge flows between the contracting company and farmers also as farmers' understanding of the contractual details. It's widely assumed that participation of farmers in contract schemes is that the results of an expected utility analysis that compares things with and without a contract (Simmons et al., 2005). Under this assumption, farmers selfselect into contract farming if their expected utility with a contract is above without (Barrett et al., 2012; Bellemare, 2012). However, our results show that the bulk of the timber farmers in Brazil has neither read nor fully understood the contract before signing it. Our example from Brazil doesn't seem to be a singular case. In other contexts farmers were also sometimes found to lack information about contract details (Singh, 2002). Farmers are often unaware of input prices, contract conditions, the precise company they signed the contract with (Simmons et al., 2005), or the company's policies (Porter \& Phillips-Howard, 1997). Written contracts are often problematic especially, as they often lack transparency when using legal terms or language that's inaccessible to farmers with relatively low education levels (Cahyadi \& Waibel, 2016). Our results also show that 78 farmers in Brazil are unaware of the initial credit amount that they're currently repaying, and will thus not make rational decisions about the inputs and assistance demanded at the time of plot establishment. This mix of quick access to credit and lack of data and transparency has also been reported elsewhere and increases the danger of farmers' indebtedness (Bijman, 2008). Farmers don't skills much they owe and the way long it'll take them to repay this debt. Being frustrated by this lack of transparency, several farmers in our sample reported that that they had applied for a credit at a proper bank, so as to pay back Unilever directly then exit the contract. However, the contract actually doesn't allow such one-time repayment, in order that many farmers feel locked into the scheme with insufficient information on the contract conditions. Such situations can easily occur when contracts seem attractive within the beginning and farmers sign longterm agreements involving large debts without having full information (Glover, 1987).

Lack of transparency increases the chance of default with the consequence that farmers may need to sacrifice autonomy over their land and also lose the chance to sell any output to the corporate (Key \&Runsten, 1999). This is often particularly problematic if farmers are highly specialised within the contracted crop and also the firm features a monopsony within the region, as is true in our case of timber extraction in Brazil. But also elsewhere, monopsony power of the contracting company has been stated as a priority (Clapp, 1994; Little \& Watts, 1994; Oya, 2012). Monopsony power makes farmers more dependent and prone to the contractor (Cai et al., 2008; Eaton \& Shepherd, 2001) and generates asymmetric power relations (Adams et al., 2019; Key \&Runsten, 1999). as an example, a monopsonist can ration procurement, lower prices, or increase quality requirements in times of supply abundance (Bijman, 2008; Glover, 1987; Huacuja, 2006). Farmers often must wait until the harvest is picked up or received by the corporate, resulting in weight losses thanks to water evaporation and potential spoilage. This way, farmers are got but what was actually delivered (Glover, 1987). For our case of timber extractors farmers in Brazil we discover that 34 you look after the farmers experienced a perceived weighing loss. And this experience is significantly correlated with the farmers' wish to exit the contract. 
Some farmers also claimed that the quantities the corporate bought were but what they'd actually delivered, which has also been reported elsewhere (Huacuja, 2006; Ochieng et al., 2017). Perceived weighing losses aren't necessarily an indication of truly opportunistic behaviour, as differences between farmers' estimated weights and actual weights can always occur. The crucial stance that is transparency in contract farming was also illustrated by Glover et al. (2014) within the Vietnamese dairy sector. The authors introduced an independent milk internal control for contract farmers through a randomised controlled trial. They found no opportunistic behaviour of the corporate regarding the reported quality of the milk. Nevertheless, the choice of getting the milk quality verified by an independent laboratory led to a big increase within the farmers' production investments and productivity. Hence, the perceived opportunistic behaviour of the contracting company introduces a further risk which will influence the farmers' production decisions and lower the potential benefits of contracts. The crucially targeted requirement of transparency and the benign trust for farmers' satisfaction is further supported by studies that investigated farmers' preferences for contract farming with economic analysis of choice experimental approaches. Additionally to overcoming output and input market uncertainty, farmers often prefer contracts with low possibility for potentially unpredictable harvest rejections (Omta, \&Abebe, 2021; Wolini et al., 2017). This accrues the importance given to transparent decision making, policies and right to information of the fellow citizens of this nation.

\section{CONCLUSION}

Much of the prevailing literature on contract farming in developing countries focusses on the question whether contracting is economically beneficial for smallholders. Empirical studies confirm that smallholders often enjoy contracts through higher yields and incomes. Nevertheless, high dropout rates from contract schemes are observed, reasons of which haven't been analysed sufficiently. The empirical example from the timber sector in Brazil presented here underlines the importance of investigation beyond purely economic indicators. Our data revealed that farmers weren't sufficiently informed about the contracts they signed and are mostly unaware of the quantity of debt they need with the corporate. This lack of transparency increases farmers' uncertainty and causes mistrust. Many farmers believe that the corporate behaves opportunistically, and this belief is significantly correlated with the farmers' wish to exit the scheme. We should always stress that we've no indication of true opportunistic behaviour by the corporate. Moreover, it's important to spotlight that the farmers have actually benefited substantially from the contract scheme in terms of upper profits and incomes. These gains aren't always so obvious for farmers. Most of them are far better off today than they were several years ago before the contract scheme had started, but farmers certainly cannot skills their situation would have developed had they not signed the contract. During this case, farmers' satisfaction with the contracts seems to be influenced more by perceptions than by actual benefits. In other words, farmers' perceptions matter and wish to be accounted for by the contracting company when the wish is to develop interdependent and lasting business relationships. While similar issues were also reported for other contract schemes in various countries, problems with mistrust and lack of transparency have received relatively little attention within the quantitative literature to elucidate smallholder dissatisfaction, dropouts, and possibly the entire breakdown of smallholder contract schemes. One policy implication is that contracts got to be clearly laid out in a language that's accessible to farmers. One research implication is that studies evaluating the success of contract farming from a broader perspective got to transcend narrowly defined economic indicators.

\section{REFERNCES}

Carter, M. R., Little, P. D., Mogues, T. and Negatu, W. 2005. "Poverty traps and environmental shocks: tracking the impacts of natural disasters on assets in Ethiopia and Honduras, working paper". University of Wisconsin. (Google Scholar)

Carter, M. R. and May, J. 1999. Poverty, livelihood and class in rural South Africa. World Development, 27: 1-20. (Crossref), (Web of Science $\left.{ }^{\circledR}\right)$, (Google Scholar)

Carter, M. R. and May, J. 2001. One kind of freedom: the dynamics of poverty in post-apartheid South Africa. World Development, 29: 1987-2006. (Crossref), (Web of Science $\left.{ }^{\circledR}\right)$, (Google Scholar)

DeLong, J. B. 1988. Productivity growth, convergence, and welfare: comment. American Economic Review, 78(5) (Google Scholar)

Dercon, S. 1998. Wealth, risk and activity choice: cattle in Western Tanzania. Journal of Development Economics, 55: 1-42. (Crossref), (Web of Science $\left.{ }^{\circledR}\right)$, (Google Scholar)

Dercon, S. 2004. Growth and shocks: evidence from rural Ethiopia. Journal of Development Economics, 74: 309-329. (Crossref), (Web of Science $\left.{ }^{\circledR}\right)$, (Google Scholar)

Dercon, S. and Krishnan, P. 1996. Income portfolios in rural Ethiopia and Tanzania: choices and constraints. Journal of Development Studies, 32: 850-875. (Taylor \& Francis Online), (Web of Science $\left.{ }^{\circledR}\right)$, (Google Scholar)

Easterly, W. and Levine, R. 1997. Africa's growth tragedy: policies and ethnic divisions. Quarterly Journal of Economics, 112: 12031250. (Crossref), (Web of Science $\left.{ }^{\circledR}\right)$, (Google Scholar)

Elbers, C., Gunning, J. W. and Kinsey, B. H. 2002. "Convergence, shocks and poverty, Tinbergen Institute Working Paper 2002035/2". (Google Scholar)

Esteban, J. and Ray, D. 1994. On the measurement of polarization. Econometrica, 62: 819-852. (Crossref), (Web of Science $\left.{ }^{\circledR}\right)$, (Google Scholar)

Feder, G. and Nishio, A. 1998. The benefits of land titling and registration: economic and social perspectives. Land Policy Studies, 15: 25-43. (Google Scholar)

Fiaschi, D. and Lavezzi, A. M. 2003. Distribution dynamics and nonlinear growth. Journal of Economic Growth, 8: 379-401. (Crossref), (Web of Science $\left.{ }^{\circledR}\right)$, (Google Scholar)

Field, E. 2003. "Entitled to Work: Urban Property Rights and Labor Supply in Peru Harvard University working paper". (Google Scholar)

Finan, F., Sadoulet, E. and de Janvry, A. Measuring the poverty reduction potential of land in Mexico. Journal of Development Economics, (forthcoming) (Google Scholar)

Foster, J., Greer, J. and Thorbecke, E. 1984. A class of decomposable poverty measures. Econometrica, 52(3): 761-766. (Crossref), (Web of Science $\left.{ }^{\circledR}\right)$, (Google Scholar)

Galor, O. and Zeira, J. 1993. Income distribution and macroeconomics. Review of Economic Studies, 60(1): 35-52. (Crossref), (Web of Science $\left.{ }^{\circledR}\right)$, (Google Scholar)

Gonzalez-Vega, Claudio. 1977. Interest rate restrictions and income distribution. American Journal of Agricultural Economics, 59(5): 973-976. (Google Scholar)

Grootaert, C. and Kanbur, R. 1995. The lucky few amidst economic decline: distributional change in Cote d'Ivoire as seen through panel datasets, 1985-1988. Journal of Development Studies, 31: 603-619. (Taylor \& Francis Online), (Web of Science ${ }^{\circledR}$ ), (Google Scholar)

Hansen, Bruce. 2000. Sample splitting and threshold estimation. Econometrica, 68: 575-603. (Crossref), (Web of Science $\left.{ }^{\circledR}\right)$, (Google Scholar) 